\title{
Peningkatan kualitas air dengan meggunakan sistem filtrasi pada pengolahan air baku
}

\author{
Sekar Dwi Rizki a,* \\ a Mahasiswa Magister Teknik Sipil, Universitas Lampung, Jl. Soemantri Brojonegoro No. 1 Bandar Lampung 35145, Indonesia
}

\section{H I G H L I G H T S}

- Telah dilakukan analisis terhadap kualitas air baku untuk parameter fisik kekeruhan dan sedimentasi sebelum dan sesudah dimasukkan ke instalasi pengolahan air di Desa Bernung, Kabupaten pesawaran.

- Kualitas air baku tidak memenuhi baku mutu dan perlu pengolahan sebelum digunakan, namun setelah air melewati instalasi pengolahan air yang terdapat material filter di dalamnya, air baku mengalami perbaikan kualitas.

\section{N F O ART IK E L}

\section{Riwayat artikel:}

Diterima 20 Oktober 2020

Diterima setelah diperbaiki 9 Desember 2020

Diterima untuk diterbitkan 15 Januari 2021

Tersedia secara online 01 April 2021

\section{Kata kunci:}

Kekeruhan,

sedimentasi

pengolahan air,

material filter alam.

\begin{abstract}
A B S T R A K
Air baku merupakan air tanpa pengolahan. Instalasi pengolahan dengan material filter alami digunakan untuk mengurangi kekeruhan dan sedimentasi. Penelitian ini bertujuan menganalisis kualitas air baku, kombinasi susunan filter dan menganalisis prospek pengembangan instalasi pengolahan air untuk masyarakat. Sampel diambil pada bulan oktober 2019-januari 2020 di Desa Bernung, Kecamatan Gedong Tataan. Pada penelitian ini digunakan material filter kerikil, pasir kuarsa, arang, ijuk dan zeolite. Dari lima material filter yang digunakan, material ijuk yang paling baik menurunkan parameter TDS dengan nilai $209.5 \mathrm{mg}$ /liter, sedangkan zeolite yang paling efektif menurunkan nilai parameter TSS dan turbidity dengan nilai $0.0490 \mathrm{mg} /$ liter dan 4.61 NTU. Instalasi pengolahan air dalam studi ini dapat diterapkan untuk daerah dampak bencana banjir maupun kekeringan, dan dikhususkan untuk wilayah pedesaan dengan ekonomi menengah ke bawah karena mudah dan ekonomis.
\end{abstract}

Diterbitkan oleh Jurusan Teknik Sipil Universitas Lampung

\section{Pendahuluan}

Air merupakan kebutuhan dasar manusia. Air sangat diperlukan untuk ketahanan bumi dan pembangunan yang berkelanjutan [1]. Air yang dibutuhkan untuk kehidupan manusia adalah air bersih, namun air bersih yang siap untuk dikonsumsi hanya tersedia $0.003 \%$ di dunia [2]. Baku mutu yang digunakan dalam kategori air bersih di Indonesia antara lain Permenkes No. 32 Tahun 2017 dan PP No.82 Tahun 2001. Sedangkan proses filtrasi bergantung dengan lapisan yang terbentuk dan tersumbat dalam filter. Kerikil merupakan material penyaring yang sering digunakan dalam proses penyaringan air (filtrasi) [3]. Proses penyaringan air secara alami biasanya dilakukan oleh batuan - batuan alami [4]. Menurut Trismoni et al. [5] zat padat tersuspensi (TSS) adalah salah satu parameter perhitungan sedimentasi. Zat padat tersuspensi juga meng-

* Penulis koresponden.

Alamat e-mail: sekardwirizki862@gmail.com (S.D. Rizki).

Peer review dibawah tanggung-jawab Jurusan Teknik Sipil Universitas Lampung.

https://doi.org/10.23960/rekrjits.v25i1.20 urangi intensitas cahaya yang masuk ke dalam air karena merupakan partikel yang berhamburan [6].

Beberapa material yang digunakan dalam proses penyaringan air dijelaskan berikut ini. Kerikil memiliki fungsi menyaring kotoran - kotoran kasar [7]. Sedangkan pasir kuarsa memiliki fungsi menghilangkan kandungan lumpur dan tanah [8]. Selanjutnya, arang aktif yang berasal dari tempurung kelapa memiliki kemampuan mengadsorpsi senyawa fenol [9]. Selain itu, arang aktif juga mampu menyerap pengotor dalam air [10]. Bahan ijuk merupakan material filter yang dapat menurunkan kadar kekeruhan, warna dan total dissolved solid (TDS) [11]. Selanjutnya, zeolit alam mampu mengadsorpsi fenol di badan air [12].

Selanjutnya, dalam penelitian ini menggunakan lima media filtrasi yaitu kerikil, pasir kuarsa, arang, zeolite dan ijuk. Oleh karena itu, penelitian ini bertujuan menganalisis kualitas air baku untuk parameter fisik kekeruhan dan sedimentasi sebelum dan sesudah dimasukkan ke instalasi pengolahan air dan menganalisis prospek pengembangan instalasi pengolahan air untuk masyarakat. Gambar material filtrasi yang digunakan dapat dilihat pada Gambar 1. 

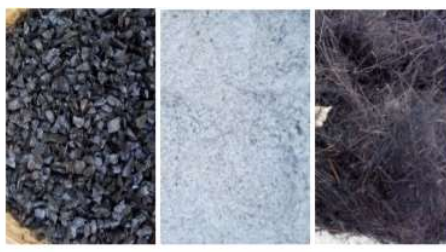

a. Kerikil

b. pasir kuarsa

c. ijuk
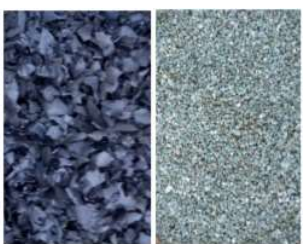

Gambar 1 Material filter

\section{Metode Penelitian}

Penelitian dilaksanakan dalam kurun waktu bulan Oktober 2019 - Januari 2020 di Desa Bernung, Kecamatan Gedong Tataan Kabupaten Pesawaran. Untuk parameter turbidity, TDS dan TSS dilakukan pengujian di Laboratorium Teknik Tanah dan Air Politeknik Negeri Lampung.

Penelitian ini menggunakan material filter dari alam yaitu batu kerikil, pasir kuarsa, arang, ijuk dan zeolite. Material filter ini dipilih karena merupakan material filter yang sering digunakan oleh masyarakat, mudah didapat dan ekonomis. Alat instalasi pengolahan air dibuat dalam ukuran tabung $30 \times 30 \times 50 \mathrm{~cm}$. Konsep desain instalasi pengolahan air dapat dilihat pada Gambar 2 .

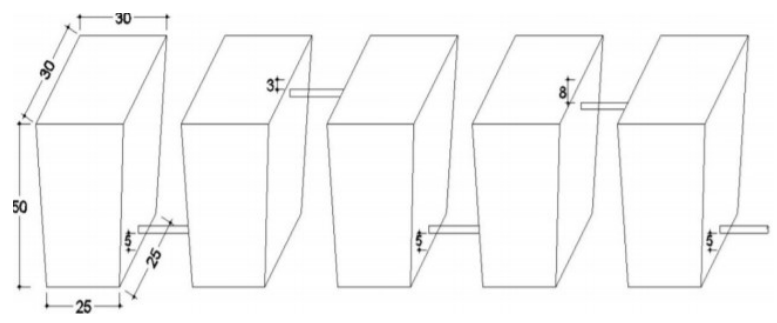

Gambar 2 Konsep desain alat pengolahan air

Ada beberapa data primer yang diambil untuk penelitian ini yaitu data kualitas air dengan parameter (turbidity, TDS dan TSS) dengan pengambilan sampel. Pengujian parameter turbidity dilakukan dengan alat turbiditymeter, parameter TDS dilakukan dengan alat TDS meter, sedangkan parameter TSS dilakukan dengan menggunakan metode gravimetri yang didasarkan pada perubahan berat setelah proses pemanasan [13]. Sedangkan data sekunder yang diperlukan adalah data mengenai program Pamsimas yang dilaksanakan di Desa Bernung.

Tahapan selanjutnya yaitu menganalisis hasil dari kualitas air yang diperoleh. Tahapan analisis berikutnya dilakukan dengan menambahkan komponen data sekunder yang diperlukan. Analisis prospek pemanfaatan dilakukan untuk mendapatkan kebermanfaatan alat instalasi pengolahan air untuk masyarakat.

\section{Hasil dan Pembahasan}

\subsection{Kualitas air baku}

Pada penelitan ini digunakan air yang mengalir ke instalasi pengolahan air menggunakan debit 0.0122 liter/s. Debit ini dipilih karena merupakan konversi dari debit tengah kebutuhan air masyarakat pedesaan yaitu 105 liter/kap/hari (Tabel 1) [14]. Baku mutu untuk parameter turbidity dan TDS mengacu pada Permenkes No. 32 Tahun 2017 [15] dengan nilai ambang batas <NTU untuk parameter turbidity dan $<1000 \mathrm{mg} /$ liter untuk parameter TDS, sedangkan untuk baku mutu parameter TSS mengacu pada PP No. 82 tahun 2001 dengan nilai ambang batas $<50$ $\mathrm{mg} /$ liter [16]. Hasil uji laboratorium air baku dapat dilihat pada Tabel 2.

Tabel 1

Perhitungan penentuan debit

\begin{tabular}{cccc}
\hline $\begin{array}{l}\text { kebutuhan air } \\
\text { (liter/kap/hari) }\end{array}$ & $\begin{array}{c}\text { Kebutuhan air* } \\
\text { (liter/hari/kk) }\end{array}$ & $\begin{array}{c}\text { Debit** } \\
\text { (liter/s) }\end{array}$ & $\begin{array}{c}\text { waktu penentuan } \\
\text { debit*** } \\
\text { (s) }\end{array}$ \\
\hline 105.00 & 525.00 & 0.01215 & 24.69 \\
\hline $\begin{array}{l}\text { Ket: *asumsi satu kk=5 orang } \\
\text { **asumsi pengaliran selama 12 jam } \\
\text { ***asumsi waktu yang diperlukan dalam } 300 \mathrm{ml}\end{array}$
\end{tabular}

Uji kualitas air baku pada penelitian ini dilakukan sebanyak tiga kali. Pada tiga kali pengambilan sampel, sampel ke-1 dan ke-2 tidak memenuhi baku mutu dengan nilai turbidity $>20$ NTU, sedangkan pengambilan sampel ke-3 memenuhi baku mutu dengan nilai 18.375 NTU. Nilai rata-rata dari parameter turbidity adalah 23.065 NTU dimana air baku tidak memenuhi baku mutu yang disyaratkan. Nilai TDS dan TSS masih memenuhi syarat baku mutu dengan nilai ratarata TDS $343.5 \mathrm{mg} /$ liter dan parameter TSS memiliki nilai rata-rata $0.1298 \mathrm{mg} /$ liter.

Tabel 2

Hasil uji laboratorium air baku

\begin{tabular}{ccrrrr}
\hline $\begin{array}{c}\text { Kode } \\
\text { Sampel }\end{array}$ & $\begin{array}{c}\text { Material } \\
\text { Penyaring }\end{array}$ & $\begin{array}{c}\text { Turbidity } \\
\text { NTU }\end{array}$ & $\begin{array}{c}\text { TDS } \\
\text { (mg/liter) }\end{array}$ & $\begin{array}{c}\text { TSS } \\
(\mathrm{mg} / \text { liter })\end{array}$ & Bau \\
\hline A0 & tidak ada & 26.390 & 395.5 & 0.0825 & bau \\
B0 & tidak ada & 24.430 & 403.5 & 0.1510 & bau \\
D0 & tidak ada & 18.375 & 231.5 & 0.1560 & bau \\
\hline Rata-rata & & 23.065 & 343.5 & 0.1298 & \\
\hline
\end{tabular}

Pada pengambilan sampel ke-3 terjadi hujan pada hari sebelumnya. Hal ini mengakibatkan pengenceran terhadap air baku. Dapat ditarik kesimpulan bahwa air baku tidak layak untuk langsung digunakan dan perlu pengolahan. Instalasi pengolahan air dapat dilihat pada Gambar 4, sedangkan hasil kualitas air baku hasil pengujian dapat dilihat pada Tabel 2 dan Gambar 5.

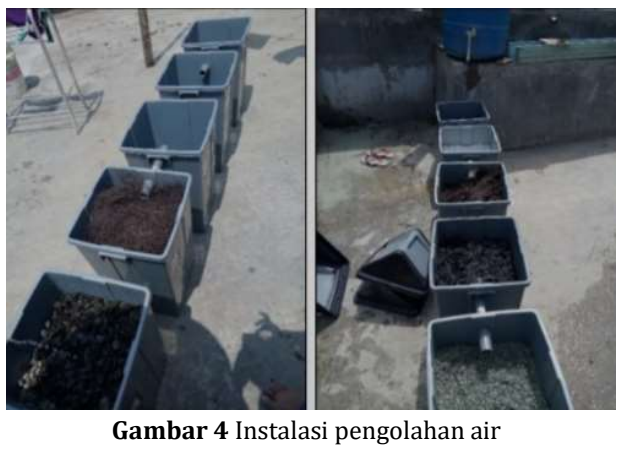

\subsection{Kualitas air pada setiap media filter}

Material filter yang digunakan pada penelitian ini adalah pasir kuarsa, kerikil, arang, ijuk dan zeolite. Instalasi pengolahan air pada penelitian in bertujuan untuk 
mengurangi kekeruhan dan sedimentasi. Berdasarkan hasil uji laboratorium bahwa media filter zeolite merupakan media yang paling memberikan hasil terbaik untuk parameter turbidity dan TTS mencapai nilai 4.61 NTU dan $0.0490 \mathrm{mg} /$ liter dibandingkan empat material filter lainnya. Menurut Syamsiah dan Hadi [12] zeolite mampu mengabsorpsi fenol di dalam mikroba dalam badan air dan digunakan untuk akuarium ikan hias. Perbandingan nilai turbidity dapat dilihat pada Gambar 6. Untuk melihat perbedaan antara air baku dan air yang telah melewati instalasi pengolahan air dapat dilihat pada Gambar 7. Untuk parameter TDS, material ijuk merupakan media yang memberikan hasil paling baik dibanding empat material filter lainnya dengan nilai $209.5 \mathrm{mg} /$ liter. Ijuk memiliki sifat absorben dan filter untuk menghilangkan bau [17]. Sedangkan air yang melewati media arang adalah satusatunya material filter yang dapat menghilangkan bau karena arang memiliki kemampuan mengurangi kekeruhan dan bau dengan sifat adsorpsi selektif [18]. Hasil uji laboratorium air baku yang telah melewati filter dapat dilihat pada Tabel 3.

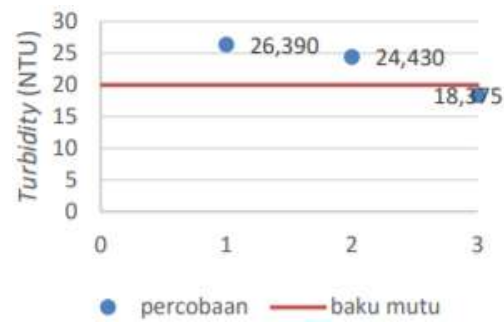

Gambar 5 Grafik perbandingan nilai turbiduty pada air baku terhadap baku mutu

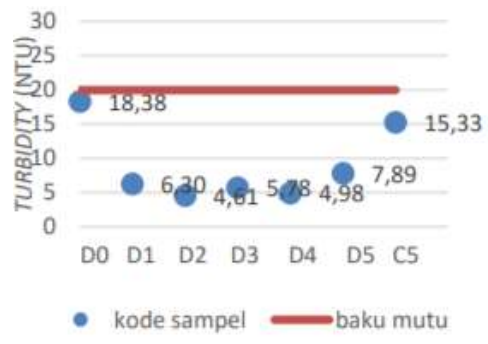

Gambar 6 Grafik perbandingan nilai turbidity pada air yang melalui material filter terhadap air baku

Tabel 3

Hasil uji laboratorium air baku yang melewati pada setiap material filter

\begin{tabular}{cccccc}
\hline $\begin{array}{c}\text { Kode } \\
\text { Sampel }\end{array}$ & $\begin{array}{c}\text { Material } \\
\text { Penyaring }\end{array}$ & $\begin{array}{c}\text { Turbidity } \\
\text { (NTU) }\end{array}$ & $\begin{array}{c}\text { TDS } \\
(\mathrm{mg} / \text { liter })\end{array}$ & $\begin{array}{c}\text { TSS } \\
(\mathrm{mg} / \text { liter })\end{array}$ & Bau \\
\hline D0 & tidak ada & 18.38 & 231.5 & 0.1560 & bau \\
D1 & kerikil & 6.30 & 218.5 & 0.0770 & bau \\
D2 & zeolite & 4.61 & 308.0 & 0.0490 & sepah \\
D3 & arang & 5.78 & 243.0 & 0.0525 & tidak bau \\
D4 & ijuk & 4.98 & 209.5 & 0.0640 & sepah \\
D5 & pasir & 7.89 & 224.0 & 0.3855 & bau \\
C5 & pasir & 15.33 & 483.5 & 0.1780 & bau \\
\hline
\end{tabular}

\subsection{Prospek pemanfaatan instalasi pengolahan air}

Prospek pengembangan instalasi pengolahan air yang dalam penelitian ini mempertimbangkan beberapa faktor

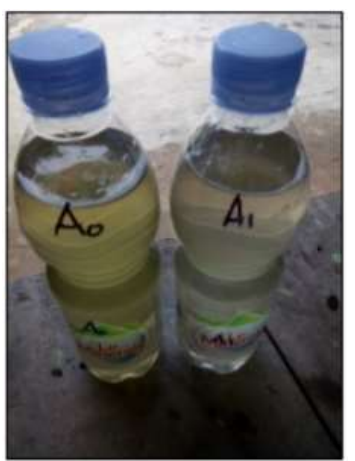

Gambar 7 Perbedaan air baku sebelum dan sesudah melewati instalasi pengolahan air

yaitu: (1) Faktor ekonomi. Instalasi pengolahan air untuk mengurangi kekeruhan dan sedimentasi dalam penelitian ini dapat diterapkan untuk wilayah bencana alam, seperti daerah banjir atau kekeringan. Pada masyarakat Desa Bernung dengan tingkat ekonomi menengah ke bawah, instalasi pengolahan air ini dapat digunakan dengan mudah, karena tidak memerlukan tingkat pendidikan yang tinggi. Pembuatan alat yang sederhana, material filter mudah di dapat dan harga ekonomis. (2) Faktor akses. Saat ini sistem penyediaan air bersih di Desa Bernung ada beberapa macam, Ada yang berasal dari mata air yang dikelola oleh Kopma dan ada yang menggunakan sumur bor secara individual. Air dari air baku Mata Air Busma akan menjadi keruh pada musim hujan. Saat ini di Desa Bernung telah dibangun bangunan reservoir kapasitas $18 \mathrm{~m}^{3}$ untuk melayani 200 SR (1000 orang) dalam program Pamsimas. Air baku yang digunakan dalam program Pamsimas tidak melewati pengolahan terlebih dahulu ketika dialirkan ke masyarakat, sehingga alat instalasi pengolahan air ini bisa diaplikasikan langsung melalui sambungan rumah dan memudahkan masyarakat untuk mengatur debit menjadi 0.00955 liter/s atau sesuai keinginan. (3) Faktor operasional. Pengguna instalasi pengolahan air dalam penelitian ini tidak memerlukan keahlian khusus, namun perlu kecermatan karena proses pembersihan harus dilakukan secara berkala untuk menjaga kualitas air. Berdasarkan wawancara dengan beberapa sumber, material filter pasir kuarsa, zeolite dan kerikil biasanya perlu dibersihkan dalam satu bulan sekali. sedangkan material ijuk dan arang perlu diganti selama tiga bulan sekali.

\section{Simpulan}

Kualitas air baku tidak memenuhi baku mutu dan perlu pengolahan sebelum digunakan yaitu rata-rata 23.065 NTU. Untuk parameter TDS dan TSS masih memenuhi baku mutu $343.5 \mathrm{mg} /$ liter dan $0.1298 \mathrm{mg} /$ liter. Setelah air melewati instalasi pengolahan air yang terdapat material filter di dalamnya, air baku mengalami perbaikan kualitas. Pada parameter TDS material filter ijuk paling efektif dengan nilai sebesar TDS $209.5 \mathrm{mg} / \mathrm{liter}$ dan paling efektif menurunkan parameter turbidity 4.61 NTU dan TSS 0.0490 $\mathrm{mg} /$ liter. Parameter sedimentasi mempengaruh parameter kekeruhan dimana partikel yang mengendap memberikan kontribusi terhadap kekeruhan yang terjadi. Berdasarkan nilai TSS dan TDS yang mewakili parameter sedimentasi, material zeolite merupakan material yang paling efektif untuk mengurangi kekeruhan. Instalasi pengolahan air yang 
pada penelitan ini dapat diaplikasikan untuk masyarakat yang kesulitan mendapatkan air bersih karena air baku yang tidak memenuhi kualitas. Berdasarkan faktor ekonomi, instalasi pengolahan air dalam penelitian ini cukup ekonomis, pembuatannya sederhana dan material filter yang mudah didapat sangat tepat untuk diterapkan kepada masyarakat menengah ke bawah. Untuk faktor akses, intalasi pengolahan air dalam penelitian ini dapat diterapkan di Desa Bernung yang memiliki reservoir kapasitas $18 \mathrm{~m}^{3}$ berasal dari program Pamsimas yang dapat langsung diakses dari sambungan rumah. Pada faktor operasional, instalasi pengolahan air dalam penelitian ini tidak memerlukan keahlian khusus namun pemeliharaannya harus teratur dan cermat.

\section{Daftar Pustaka}

[1] Falkenmark, M., Wang-Erlandsson, L., Rockström, J.: Understanding of water resilience in the anthropocene. Journal of Hydrology X, 2, 100009. 2018. https://doi.org/10.1016/j.hydroa.2018.100009

[2] Oktavianto, A., Nurhayati, N., Suswati, E.: Evaluasi keamanan sumber air minum desa Mojo Kecamatan Padang Kabupaten Lumajang. Jurnal Agroteknologi, 08(02), 2014.

[3] Pemerintah Republik Indonesia. Lampiran PP No. 82 Tahun 2001. Jakarta: Pemerintah Republik Indonesia. 2001.

[4] Marchi, L., Comiti, F., Crema, S., Cavalli, M.: Channel control works and sediment connectivity in the european alps. Science of the Total Environment, 668, 2019, 389-399. https://doi.org/10.1016/j.scitotenv.2019.02.416

[5] Trismono, C., Krisna, A. B., Cahyono, K., Kunci, K.: Analisa sebaran TSS (total suspended solid) dengan menggunakan citra satelit aqua modis tahun 2005-1011 (studi kasus: pesisir pantai Surabaya-Sidoarjo), Geoid, 08, 2012. 29-38.

[6] Hu, Y., Zhao, D., Qin, Y., Wang, X.: An order determination method in direct derivative absorption spectroscopy for correction of turbidity effects on COD measurements without baseline required. Spectrochimica Acta Part A: Molecular and Biomolecular Spectroscopy, 226, 2020, 117646. https://doi.org/10.1016/j.saa.2019.117646
[7] Fajri, M. N., Handayani, Y. L., Sutikno, S.: Efektifitas rapid sand filter untuk meningkatkan kualitas air daerah gambut di Provinsi Riau. Jom FTEKNIK, 4(1), 2017, 1-9.

[8] Jenti, U. B., Nurhayati, I.: Pengaruh penggunaan media filtrasi terhadap kualitas air sumur gali di Kelurahan Tambak Rejo Waru Kabupaten Sidoarjo. Teknik Waktu, 12(2), 2014.34-38.

[9] Kurniati, F. D., Pardoyo, P., Suhartana, S.: Sintesis arang aktif dari tempurung kelapa dan aplikasinya untuk adsorpsi asap cair. Jurnal Kimia Sains Dan Aplikasi, 14(3), 2011, 72-76.

[10] Nustini, Y., Allwar, A.: Pemanfaatan limbah tempurung kelapa menjadi arang tempurung kelapa dan granular karbon aktif guna meningkatkan kesejahteraan Desa Watuduwur, Bruno, Kabupaten Purworejo. Asian Journal of Innovation and Enterpreneurship, 04 (September), 2019, 217-226.

[11] Sulastri, S., Nurhayati, I.: Pengaruh media filtrasi arang aktif terhadap kekeruhan, warna dan TDS pada air telaga di Desa Balongpanggang. Jurnal Teknik Waktu, 12(1), 2014, 43-47.

[12] Syamsiah, S., Hadi, I. S.: Adsorption cycles and effect of microbial population on phenol removal using natural zeolit. Separation and Purification Technology, 34(1-3), 2004, 125133. https://doi.org/10.1016/S1383- 5866(03)00186-2

[13] Pemerintah Republik Indonesia.: Peraturan Pemerintah Republik Indonesia Nomor 82 Tahun 2001. Jakarta: Pemerintah Republik Indonesia. 2001

[14] Triatmodjo, B.: Hidrologi Terapan. Yogyakarta: Beta Offset. 2008.

[15] Kementerian Kesehatan.: Permenkes No.32 Tahun 2017 tentang Standar Baku Mutu Kesehatan Lingkungan dan Persyaratan Kesehatan Air untuk Keperluan Higiene Sanitasi, Kolam Renang, Solus Per Aqua, dan Pemandian Umum. Kementerian Kesehatan Republik Indonesia. Jakarta: Kementerian Kesehatan Republik Indonesia. 2017.

[16] Windaryati, L., Ngatijo, N., Pranjono, P., Torowati, T.: Penentuan kadar uranium dalam serbuk UO2 dari yellow cake secara potensiometri dan gravimetro. Jurnal Forum Nuklir (JFN), 10(2), 2016, 75-80.

[17] Fazil, M., Adhar, S., Ezraneti, R.: Efektivitas penggunaan ijuk, jerami, padi dan ampas tebu sebagai filter air pada pemeliharaan ikan mas koki (carassius auratus). Acta Aquatica, 1(4), 2017, 37-43.

[18] Jamilatun, S., Setyawan, M.: Pembuatan arang aktif dari tempurung kelapa dan aplikasinya untuk penjernihan asap cair. Spektrum Industri, 12(1), 73. 2018. https://doi.org/10.12928/si.v12i1.1651 